\title{
Water softeners add comfort and consume water - comparison of selected centralised and decentralised softening technologies
}

Tang, Camilla; Merks, Cornelis Wilhelmus Adrianus Maria; Albrechtsen, Hans-Jørgen

Published in:

Water Science and Technology: Water Supply

Link to article, DOI:

$10.2166 /$ ws.2019.088

Publication date:

2019

Document Version

Peer reviewed version

Link back to DTU Orbit

Citation (APA):

Tang, C., Merks, C. W. A. M., \& Albrechtsen, H-J. (2019). Water softeners add comfort and consume water comparison of selected centralised and decentralised softening technologies. Water Science and Technology: Water Supply, 19(7), 2088-2097. https://doi.org/10.2166/ws.2019.088

\section{General rights}

Copyright and moral rights for the publications made accessible in the public portal are retained by the authors and/or other copyright owners and it is a condition of accessing publications that users recognise and abide by the legal requirements associated with these rights.

- Users may download and print one copy of any publication from the public portal for the purpose of private study or research.

- You may not further distribute the material or use it for any profit-making activity or commercial gain

- You may freely distribute the URL identifying the publication in the public portal 
1 Water softeners add comfort and consume water -

2 comparison of selected centralised and decentralised

3 softening technologies

Camilla Tang*, Cornelis Wilhelmus Adrianus Maria Merks**, Hans-Jørgen Albrechtsen*

* Technical University of Denmark, Department of Environmental Engineering, Bygningstorvet, Bygning 115, 2800 Kgs. Lyngby, Denmark, catang@env.dtu.dk, hana@env.dtu.dk

** Witteveen+Bos International Projects B.V., Van Twickelostraat 2, P.O. Box 233, 7400 AE Deventer, the Netherlands, cor.merks@witteveenbos.com

9 Keywords: CCPP; decision making; drinking water treatment; hard and soft drinking water; water treatment 10 residuals; water use

11 Abstract

Selected technologies for centralised or decentralised drinking water softening were evaluated based on technical, economic, environmental and aesthetic indicators to identify the optimal treatment technology for a given setting. To achieve this, we demonstrated that a number of important indicators beyond hardness reduction and costs have to be included. All the evaluated centralised softening technologies could reduce water hardness to the target of $1.3 \mathrm{mmol} / \mathrm{L}$ at the Dutch drinking water treatment plant Beilen. CARIX ${ }^{\circledR}$ treatment and pellet softening with $\mathrm{Ca}(\mathrm{OH})_{2}$ resulted in a lower $\mathrm{CCPP}_{90}(0.25-0.30 \mathrm{mmol} / \mathrm{L})$ than nanofiltration (0.30-0.35 mmol/L). Decentralised reverse osmosis had a water consumption of $>100 \%$, whereas decentralised cation exchange had a water consumption of $2.5-4.5 \%$ which was comparable to centralised pellet softening (3.6\%). Except for the electronic water conditioner that does not remove water hardness, the decentralised technologies were 710 times more expensive than the centralised technologies per $\mathrm{m}^{3}$ of softened water. The centralised softening technologies furthermore ensured supply of softened water to all customers in a water supply zone. Thus, in areas with hard water and limescale problems investment in centralised softening at the local water utility is more optimal than widespread implementation of decentralised systems.

\section{Introduction}

Hard drinking water increases the formation of limescale (mainly calcium carbonate $\left(\mathrm{CaCO}_{3}\right)$ ) in household appliances and installations, which e.g. increases the use of descaling agents and reduces the service life of e.g. kettles and water heaters (Brink et al., 2004). Hard drinking water can also result in increased soap consumption (WHO, 2011). Limescale formed on the inside of water pipes may reduce the flow capacity and may eventually even block it entirely. Furthermore, hard water can increase the dissolubility of lead and copper from distribution pipes and appliances, which may result in increased concentration in the drinking water (Hofman et al., 2007). Hard water is caused by the presence of multivalent cations, mainly calcium $\left(\mathrm{Ca}^{2+}\right)$ and magnesium $\left(\mathrm{Mg}^{2+}\right)$ (van der Bruggen et al., 2009).

Centralised drinking water softening was implemented in the Netherlands in the 1980's to reduce the release of lead into drinking water (van den Hoven et al., 1998), but nowadays the driving force for implementing centralised softening has shifted towards a consumer comfort perspective by reducing limescale (Hofman et al., 2007). Water utilities can add softening to existing or new drinking water treatment plants (DWTPs), thereby centrally providing softened drinking water to their customers. When centralised softening treatment is not provided, households and businesses sometimes install their own decentralised water softeners as point-of-entry or point-of-use water treatment devices. 
Several softening technologies are available and they vary in terms of hardness and limescale reduction, but also in terms of e.g. water consumption, maintenance requirements, residuals, capital cost and operating expenditures, environmental impact and effect on corrosion. Despite the widespread implementation of both centralised and decentralised drinking water softening (e.g. Hofman et al., 2007; van der Bruggen et al., 2009), the overall performance of centralised versus decentralised softening technologies has not been evaluated.

The aim of this study was to evaluate selected technologies for centralised or decentralised drinking water softening using an array of relevant indicators including technical, economic, environmental and aesthetic criteria. A secondary aim was to evaluate the overall performance of centralised versus decentralised drinking water softening technologies.

\section{Methods}

\section{Selection of indicators}

The selection of indicators for evaluating softening technologies was inspired by a framework, developed to evaluate point-of-use and point-of-entry water treatment technologies (Hamouda et al., 2010). We adapted these criteria by including technical, economic, environmental and aesthetic indicators. Indicators for comparing softening technologies should reflect the motivation for drinking water softening, and in this case the driving forces were limescale and soap use reduction.

- Hardness reduction: The softening technologies included in this study all reduce water hardness (i.e. removal of calcium and possibly also magnesium) except the physical water conditioner. However, the mechanisms for hardness removal vary, and for some water types it may not be possible to meet the target hardness after softening.

- Limescale reduction, expressed by the Calcium Carbonate Precipitation Potential at $90{ }^{\circ} \mathrm{C}\left(\mathrm{CCPP}_{90}\right)$ : The CCPP quantifies the amount of $\mathrm{CaCO}_{3}$ that can dissolve or precipitate from the water and provides a better estimate for limescale than e.g. the Langelier saturation index (Brink et al., 2004).

- Water consumption: Drinking water softening is typically associated with a water use. The amount of water used depends on the softening technology and its mechanism for hardness removal.

- The quantity and quality of residuals: Some softening technologies, e.g. pellet softening, produce both wastewater and solid residuals (van Dijk \& Wilms, 1991). The solid residuals can either represent a resource, if they can be reused, or waste if reuse applications are unavailable.

- Operating and maintenance requirements: Operating and maintenance vary depending on the softening technology, as well as the size and capacity of the DWTP, thereby affecting operating expenditures differently. For decentralised softening, operation is done by members of the household and maintenance is typically done by professionals (van der Bruggen et al., 2009; BWT, 2019c).

- Cost per $\mathbf{m}^{3}$ softened drinking water: Both capital cost and operating expenditures were included when evaluating the different technologies.

\section{Evaluation of centralised softening technologies}

Three technologies were selected to represent centralised drinking water softening with different mechanisms for hardness removal: pellet softening with $\mathrm{Ca}(\mathrm{OH})_{2}$, anaerobic nanofiltration and CARIX ${ }^{\circledR}$ treatment. Each technology was evaluated with respect to the 
89

90

91

92

93

94

95

96

97

98

99

100

101

102

103

104

105

106

107

108

109

110

111

112

113

114

115

116

117

118

119

120

121

122

123

124

125

126

127

128

129

130 Dosing a base changes the carbonic acid equilibrium, resulting in spontaneous 131 crystallisation of $\mathrm{CaCO}_{3}$. In pellet softening, the base is dosed in a fluidized bed reactor with

indicators based on literature, the authors' personal experience with implementing water softening, and personal communications with technology suppliers (Veolia, 2018).

The technologies were evaluated using the Dutch DWTP Beilen as case, which is operated by the water utility Drenthe (WMD). DWTP Beilen has a total annual water abstraction permit of 4 million $\mathrm{m}^{3}$ groundwater, with a design capacity of $650 \mathrm{~m}^{3} / \mathrm{h}$. The groundwater has a hardness of $2.0 \mathrm{mmol} / \mathrm{L}(1 \mathrm{mmol} / \mathrm{L}=100 \mathrm{mg} \mathrm{CaCO} / \mathrm{L})$ and the target water hardness selected by the water utility was $1.3 \mathrm{mmol} / \mathrm{L}$. The groundwater also contains e.g. methane, iron, manganese and ammonia that must be removed to meet drinking water guidelines and that may interfere with softening (Supplementary Material A).

The cost estimates for each of the three potential water treatment schemes were at the level of feasibility study with an accuracy of $\pm 30 \%$ for capital cost and $\pm 20 \%$ for operating expenditures. The cost estimates for pellet softening with $\mathrm{Ca}(\mathrm{OH})_{2}$ and for membrane separation technologies were developed by the water utility Drenthe (Wessels \& GalamaTirtamarina, 2018) with the Standard Cost Calculator Drinking Water (Royal HaskoningDHV, 2019), and the assumptions and unit prices listed in Supplementary Material B. The cost estimate for anaerobic nanofiltration was based on these cost estimates. Veolia developed the cost estimate for CARIX ${ }^{\circledR}$ for DWTP Beilen in December 2018 (Veolia, 2018) and supplies the CARIX ${ }^{\circledR}$ technology.

\section{Evaluation of decentralised softening technologies}

Reverse osmosis, "traditional" cation exchange with different mechanisms for removing water hardness and one physical water conditioner were selected to represent decentralised drinking water softening. Generally, scientific literature about decentralised softening technologies is limited. We contacted various suppliers of decentralised softening devices, however, none responded within the timeframe of this study. Consequently, the evaluation of decentralised technologies was made based on publicly accessible data by various suppliers and limited scientific references.

The cost estimates for cation exchange were based on an example calculation by the technology supplier BWT in Denmark for the AQA basic unit and were affected by the initial water hardness only (BWT, 2019c). The calculations were based on drinking water with an initial water hardness of $2.0 \mathrm{mmol} / \mathrm{L}$ and operating expenditures were calculated for a household of 3 people with the average Danish daily water use of 107 litres per person (BWT, 2019c). This example calculation was also used for the cost estimates for the other decentralised softening technologies. The cost estimates included the purchase price and operational expenditures e.g. regeneration salt or filter replacement, excluded installation and water consumption, and were expressed as costs per $\mathrm{m}^{3}$ softened drinking water produced.

\section{Softening technologies}

Different softening technologies have different mechanisms for hardness removal (Table 1). Some softening technologies, e.g. lime-soda ash softening, pellet softening and CARIX ${ }^{\circledR}$ are complex and require special facilities and are therefore applicable only to centralised systems where all treatment can be accomplished at a central location. Other technologies, e.g. ion exchange, distillation and membrane separation, are applicable both for centralised and decentralised systems (Table 1).

\section{Softening technologies for centralised softening}

\section{Pellet softening}


132 seeding grains. $\mathrm{CaCO}_{3}$ crystallises on the surface of the seeding grains, forming pellets.

133 Calcium hydroxide $\left(\mathrm{Ca}(\mathrm{OH})_{2}\right)$ or sodium hydroxide $(\mathrm{NaOH})$ is typically used as base 134 chemical (van Dijk \& Wilms, 1991).

135 In pellet softening, nearly only $\mathrm{Ca}^{2+}$ is removed from the water due to the $\mathrm{pH}$ conditions 136 inside the reactor. Thus, hardness caused by $\mathrm{Mg}^{2+}$ remains in the water, which limits the achievable softening depth (i.e. hardness reduction). The CCPP reduction depends on the choice of base chemical. $\mathrm{Ca}(\mathrm{OH})_{2}$ removes 2 moles $\mathrm{HCO}_{3}{ }^{-}$for each mole $\mathrm{Ca}^{2+}$ removed, which decreases CCPP more compared to $\mathrm{NaOH}$ where 1 mole $\mathrm{HCO}_{3}{ }^{-}$is removed from the water for each mole $\mathrm{Ca}^{2+}$ removed (van Dijk \& Wilms, 1991).

$\mathrm{CaCO}_{3}$ pellets are the main residual from pellet softening and may be reused in industry. The water use for pellet softening is primarily associated with sand washing and pellet withdrawal and is typically $1 \%$. Pellet softening requires post treatment by filtration, which may also result in an increase of wastewater and sludge from backwashing of the filters.

Pellet softening also requires storage facilities for the chemicals (the base and $\mathrm{CO}_{2}$ for $\mathrm{pH}$ adjustment after softening), seeding grains and the produced pellets, which require maintenance. The pellet reactor itself requires maintenance every 1-2 years, predominantly for removal of limescale. The storage facilities contribute substantially to the capital cost where economy of scale affects the contribution of these facilities to the overall investment of pellet softening. In general, the larger the plants' capacity the lower the cost per $\mathrm{m}^{3}$ of softened water.

\section{CARIX ${ }^{\circledR}$}

Carbon Dioxide Regenerated Ion Exchange (CARIX ${ }^{\circledR}$ ) can be designed for two operating modes: partial desalination or softening only (Höll \& Hagen, 2002). In partial desalination process the ion exchange resin is a mixed bed of a weak-acid cation resin in the free acid form $\left(\mathrm{H}^{+}\right)$and a strong-base anion resin in the hydrogen carbonate form $\left(\mathrm{HCO}_{3}{ }^{-}\right) . \mathrm{Ca}^{2+}$ and $\mathrm{Mg}^{2+}$ in the feedwater are exchanged with $\mathrm{H}^{+}$ions and $\mathrm{SO}_{4}{ }^{2-}, \mathrm{NO}_{3}{ }^{-}$and $\mathrm{Cl}^{-}$are exchanged with $\mathrm{HCO}_{3}{ }^{-} \cdot \mathrm{CO}_{2}$ is formed as a result of the ion exchange and is removed from the water by air stripping or degassing. This reduces the $\mathrm{HCO}_{3}{ }^{-}$concentration of the water thereby reducing the CCPP. In softening mode, the exchange resin consists of the weak-acid cation resin in the free acid form only (Höll \& Hagen, 2002).

Once the resin is saturated, it is regenerated with pressurised $\mathrm{CO}_{2}$ dissolved in water, and wastewater (eluate) with the exchanged ions must be disposed, typically to a recipient. The water use for CARIX ${ }^{\circledR}$ treatment varies depending on the softening depth, since higher hardness removal requires a higher regeneration frequency, resulting in increased water consumption. Veolia reports a water usage ranging from $3.5 \%$ to $10 \%$ of the feedwater flow (Veolia, 2018). No solid residuals are formed during CARIX ${ }^{\circledR}$.

A CARIX ${ }^{\circledR}$ plant requires steel vessels for e.g. the production of regeneration water, degassing and $\mathrm{CO}_{2}$ recovery from the wastewater as well as various rotating equipment (e.g. pumps and blowers) consequently requiring some maintenance and substantially contributing to the capital cost. The total cost of CARIX ${ }^{\circledR}$ treatment is predominantly affected by the relatively high capital cost (Veolia, 2018). Currently, CARIX ${ }^{\circledR}$ is implemented at DWTPs with a capacity ranging from 20 to $600 \mathrm{~m}^{3} / \mathrm{h}$, thus predominantly at medium-sized water systems.

\section{Nanofiltration}

174 Nanofiltration is a pressure-driven membrane filtration process with pore sizes from 0.7 to 5-8 nanometres (Hoslett et al., 2018). Nanofiltration membranes reject both scale-forming $\mathrm{Ca}^{2+}$ and $\mathrm{Mg}^{2+}$ ions as well as $\mathrm{SO}_{4}{ }^{2-}$, while a fraction of e.g. $\mathrm{Na}^{+}, \mathrm{HCO}_{3}{ }^{-}$and $\mathrm{Cl}^{-}$passes the membranes (van der Bruggen \& Vandecasteele, 2003). Nanofiltration typically requires antiscalant for scaling control and possibly some hydrochloric acid to lower the $\mathrm{pH}$ of the

179 feedwater. The hardness reduction depends on the membrane type, but nanofiltration can 
180 result in a nearly complete hardness removal (both $\mathrm{Ca}^{2+}$ and $\mathrm{Mg}^{2+}$ ). The target hardness is 181 achieved by blending non-softened bypass water with softened permeate water. The mixing 182 does also allow for setting the desired CCPP.

183 The amount of wastewater (concentrate) from nanofiltration depends on the membrane 184 system design, antiscalant and acid chemical dosages and the feed pressure. The amount 185 of concentrate can range from $15 \%$ to $30 \%$ of the feedwater to a nanofiltration unit (van der 186 Bruggen \& Vandecasteele, 2003). The wastewater has a high mineral content as well as the antiscalant chemical. No solid residuals are produced during nanofiltration.

Periodical replacement of membranes is needed, and the frequency depends on feedwater quality, feedwater treatment, membrane system design and operation. Pre-treatment of feedwater is usually required to decrease membrane fouling. Alternatively, membrane separation technologies can be implemented on anaerobic groundwater which reduces the risk of membrane fouling and the maintenance requirements. Time necessary for operation and maintenance of a membrane softening plant is relatively limited due to the high degree of process automation. The operating expenditures are predominantly related to the energy requirements of the high-pressure feed pump and to the chemical cost.

196 Nanofiltration softening plants are designed and constructed as modular plants. Thus, the overall investments and thereby the cost per $\mathrm{m}^{3}$ are affected by the size and capacity of the DWTP, and by the required amount of water that must pass the nanofiltration membrane.

\section{Softening technologies for decentralised softening}

199

200

201

202

203

204

205

206

207

208

209

210

211

212

213

214

215

216

217

218

219

220

221

222

223

224

The following softening technologies do not require special facilities and are therefore also applicable for decentralised water systems. Cation exchange and reverse osmosis were included in this study, based on drinking water as feed water.

\section{Cation exchange}

The units for the cation exchange softening technology are typically equipped with a strongacid resin that replaces $\mathrm{Na}^{+}$adsorbed to it with $\mathrm{Ca}^{2+}$ and $\mathrm{Mg}^{2+}$ present in the drinking water. Once the resin is saturated, regeneration takes place with sodium chloride (salt), and wastewater (eluate) with the $\mathrm{Ca}^{2+}, \mathrm{Mg}^{2+}$ and $\mathrm{Cl}^{-}$ions must be disposed (AWWA, 2016).

Water leaving the cation exchanger has close to zero hardness and must be blended with non-softened bypass drinking water to achieve the desired hardness (BWT, 2019a). Cation exchange softening does not alter the $\mathrm{pH}$ or alkalinity of the water. Consequently, the CCPP reduction is lower than for the other included softening technologies, unless close to zero hardness water is considered. The water use for regeneration can be as low as between 2.5-4.5\%, depending on water softener size and model (BWT, 2019a).

\section{Reverse osmosis}

Reverse osmosis uses the most dense membranes and can remove essentially all organic and inorganic constituents but is not an impermeable barrier to ionic species. Even though $>95 \%$ rejection can be attained, complete rejection of target pollutants is hard to achieve (Bellona et al., 2004). Due to the high rejection, reverse osmosis produces water that has nearly zero hardness. Decentralised reverse osmosis is predominantly installed as pointof-use systems without the possibility to blend with non-softened water (Express Water, 2019).

Reverse osmosis membranes in decentralised systems are typically a part of a so-called "five stage drinking water solution" (Express Water, 2019) with the stages: mechanical filtration, activated carbon adsorption, ultrafiltration, reverse osmosis and activated carbon adsorption. The systems operate on incoming household water pressure and without antiscalant and/or acid chemical dosages, resulting in a high amount of concentrate to be discharged to the sewer system. According to the supplier, the typical discharge is one to 
three litres for every litre produced, which is affected by the water pressure, incoming water quality and water temperature (Express Water, 2019). The systems are maintained by replacing the different filters and the reverse osmosis membrane. The frequency of replacement depends on e.g. the incoming water hardness (Express Water, 2019).

\section{Physical water conditioners}

229 Physical water conditioners are not designed for water softening (i.e. removal of $\mathrm{Ca}^{2+}$ and $230 \mathrm{Mg}^{2+}$ from water) but to alter the characteristics of the hardness minerals within the water 231 to prevent limescale formation (Georgiou et al., 2018). The mechanisms of electronic, 232 electrostatic and magnetic water conditioners have been hypothesised (e.g. Coey, 2012), 233 but is not fully understood. Although several studies have been carried out on physical water conditioners showing a reduction in limescale formation (e.g. Georgiou et al., 2018), the effects may vary depending on the water quality (Coey, 2012) and no studies demonstrate effects in terms of e.g. reduction in soap and descaling agent use comparable to the other softening technologies included in this study.

The electronic water conditioning device by Hydropath Technology Ltd. was included in this study, which applies an electrical field to the pipe and the water contained within. According to Hydropath, the technology works by emitting a varying electrical field into the water, causing the $\mathrm{CaCO}_{3}$ particles to form in suspension, which are then washed away with the flow. The electronic water conditioners produce no wastewater and residuals (Hydropath, 2019).

\section{Evaluation of softening technologies}

\section{Water treatment schemes for centralised softening}

Different treatment schemes were required at DWTP Beilen in order to achieve the target hardness of $1.3 \mathrm{mmol} / \mathrm{L}$ depending on the softening technology (Figure 1). Aeration and rapid sand filtration or dual media filtration were necessary for removal of methane, iron, ammonia and manganese upstream of pellet softening or CARIX ${ }^{\circledR}$. CARIX ${ }^{\circledR}$ was designed to operate in softening mode with a weak-acid cation resin in the free acid form only and was followed by degassing (Veolia, 2018). Pellet softening was applied on 65\% of the filtered water and was followed by dual media filtration (Wessels \& Galama-Tirtamarina, 2018). Nanofiltration was applied directly on $45 \%$ of anaerobic groundwater (so-called split stream), followed by degassing and rapid sand filtration (Figure 1).

\section{Softening technologies for centralised water systems}

253

254

255

256

257

258

259

260

261

262

263

264

265

Despite the different technologies and treatment schemes, the costs per $\mathrm{m}^{3}$ of softened water were comparable for all three softening technologies: 0.15-0.20 USD per $\mathrm{m}^{3}$ (Table 2, Supplementary Material C). Pellet softening requires 8-12 hours per week for maintenance, which is more than nanofiltration (4-8 hours per week) and CARIX ${ }^{\circledR}(2-4$ hours per week). The target drinking water hardness of $1.3 \mathrm{mmol} / \mathrm{L}$ was met by all three softening technologies (Table 2). The $\mathrm{CCPP}_{90}$ after pellet softening with $\mathrm{Ca}(\mathrm{OH})_{2}$ and after $\mathrm{CARIX}{ }^{\circledR}$ treatment were comparable $(0.25-0.30 \mathrm{mmol} / \mathrm{L})$ and slightly better than by anaerobic nanofiltration (0.30-0.35 mmol/L). The water treatment scheme with anaerobic nanofiltration had the highest total water use $(10.5 \%)$ compared to pellet softening (3.6\%) and CARIX ${ }^{\circledR}$ (5.3\%). The wastewater from nanofiltration is highly concentrated and contains antiscalant, whereas the wastewater from CARIX ${ }^{\circledR}$ typically can be discharged to a recipient due to its lower concentration of minerals. Pellet softening produces a solid residual, pellets, as the only included technology. 
The results from DWTP Beilen represent a specific geographic case with a specific groundwater composition. Technologies should be evaluated for each specific case prior to choosing softening technology. Nonetheless, the case study provides an indication of the performance within each indicator.

\section{Technologies for decentralised water systems}

270 The cost of softened water treated by decentralised technologies varied from USD 0.3 per $\mathrm{m}^{3}$ for the electronic water conditioner to USD 2.2 per $\mathrm{m}^{3}$ for the cation exchange device (Supplementary Material D). The costs related to the water consumption were not included and hence the operating expenditures for the reverse osmosis installation will be higher due to the water use that exceeds $100 \%$.

Both cation exchange and reverse osmosis can remove nearly all water hardness (Table 3 ), whereas the electronic water conditioning device does not remove hardness. The highest reduction of $\mathrm{CCPP}_{90}$ is expected with reverse osmosis compared to cation exchange, since $\mathrm{HCO}_{3}{ }^{-}$is removed in addition to water hardness. The electronic water conditioning device may have an effect on limescale formation, but since the water composition does not change, CCPP $\mathrm{CPo}_{90}$ is not expected to change (Table 3).

280

The water consumption varies substantially for the decentralised water systems: From the electronic water conditioning device with no water use, to a reverse osmosis system where the water usage in most cases will exceed $100 \%$ of the feedwater to the unit (Table 3).

The decentralised water systems vary more in performance compared to the centralised water systems. The reverse osmosis system has the highest water usage, but also reduces $\mathrm{CCPP}_{90}$ the most. An electronic water conditioning device has the advantage that it has neither water use nor production of residuals. On the other hand, the effects on limescale reduction are uncertain.

\section{Centralised versus decentralised drinking water softening}

289 For water utilities, high water consumption of a specific technology can limit the amount of 290 drinking water produced if e.g. groundwater abstraction permits are at risk of being 291 exceeded. Furthermore, discharging wastewater to e.g. the sewer is associated with 292 increased operating expenditures unless direct discharge to a recipient is possible. For 293 households, discharging water will increase the water use and thereby increase costs. 294 However, they are not challenged by the restrictions of e.g. abstraction permits that utilities 295 experience and water consumption is hence less critical for households.

296 When a water utility decides not to invest in centralised softening treatment in areas with hard water, many households in these areas may instead implement decentralised softening. A large water consumption due to widespread decentralised softening treatment with a variety of softening technologies can also affect the water utility by an increased overall water demand, beyond the control of the water utility.

301 Except for the electronic water conditioner, the decentralised technologies were seven to 302 ten times more expensive than the centralised technologies per $\mathrm{m}^{3}$ of softened water, indicating that large-scale operation results in lower costs. Thus, it may beneficial for water utilities to consider implementing centralised softening to supply all customers with the benefits of softened water and thus avoid widespread implementation of decentralised technologies. When choosing the optimal treatment technology for either centralised or decentralised softening, a number of important indicators beyond hardness reduction and costs have to be included. Both the total water consumption of a water treatment scheme including a specific softening technology and the options for wastewater discharge and residuals must be included in the evaluation. 


\section{Conclusion}

311 We evaluated selected technologies for centralised and decentralised drinking water

312 softening. None of the included technologies performed best within all six indicators.

313 Consequently, including only hardness removal and costs when choosing a softening

314 technology may result in a less optimal choice compared to an evaluation also considering

315 e.g. the $\mathrm{CCPP}_{90}$, solid residuals and wastewater production. For the selected case study, it

316 was concluded that:

- The centralised softening technologies (CARIX ${ }^{\circledR}$, pellet softening with $\mathrm{Ca}(\mathrm{OH})_{2}$ and nanofiltration) performed equally well in terms of hardness removal at DWTP Beilen. Pellet softening with $\mathrm{Ca}(\mathrm{OH})_{2}$ and $\mathrm{CARIX}{ }^{\circledR}$ treatment resulted in the lowest $\mathrm{CCPP}_{90}$. The decentralised softening technologies (cation exchange and reverse osmosis) were able to remove nearly all water hardness, and the lowest $\mathrm{CCPP}_{90}$ was expected with reverse osmosis.

- Decentralised reverse osmosis had the highest water use (>100\%) followed by: centralised anaerobic nanofiltration (10.5\%), centralised CARIX ${ }^{\circledR} \quad(5.3 \%)$, decentralised "traditional" cation exchange (2.5 - 4.5\%), centralised pellet softening (3.6\%) and the decentralised electronic water conditioning device (no water use).

- The centralised softening technologies generally performed better than the decentralised technologies (cation exchange and reverse osmosis) in terms of costs (7-10 times cheaper than the decentralised technologies).

\section{Acknowledgements}

The authors thank water utility Drenthe for allowing us to publish the results of the feasibility study for drinking water treatment plant Beilen. We would like to thank Veolia and other technology suppliers for their contribution to this article. We thank HOFOR, NIRAS and the Technical University of Denmark for their financial support of the study.

\section{References}

AWWA 2016. WSO Water Treatment, Grades 3 \& 4. American Water Works Association

Bellona, C., Drewes, J. E., Xu, P. \& Amy, G. 2004 Factors affecting the rejection of organic solutes during NF/RO treatment - a literature review. Water Research, 38, 2795-2809.

Brink H., Slaats P.G.G., van Eekeren M.W.M. 2004. Scaling in domestic heating equipment: getting to know a complex phenomenon. Water Science and Technology. 49(2), 129-136

van der Bruggen B., Vandecasteele C. 2003. Removal of pollutants from surface water and groundwater by nanofiltration: Overview of possible applications in the drinking water industry. Environmental Pollution. $122,435-445$

van der Bruggen B., Goossens H., Everard P.A., Stemgée K.; Rogge W. 2009. Cost-benefit analysis of central softening for production of drinking water. Journal of Environmental Management. 91, 541-549

BWT 2019a. BWT Waterside Fitting and operating instructions EN. https://www.bwtuk.co.uk/en/business/products/domesticproducts/water-softener/BWTWSSeries/Pages/default.aspx [accessed 30 April 2019]

BWT 2019b. Scale https://www.bwtuk.co.uk/en/business/products/domesticproducts/scalereduction/Pages/default.aspx [accessed 30 April 2019]

BWT 2019c. Produktinfo: AQA Basic \& AQA life blødgøringsanlæg (Product information: AQA Basic \& AQA life softening installations). http://kalkfrithjem.bwt.dk/bwt-bloedgoeringsanlaegproduktinfo/?media=bwtwebshop [accessed 30 April 2019]

Coey J.M.D. Magnetic water treatment - how might it work?. Philosophical Magazine. 92(31), 3857-3865

van Dijk J., Wilms D. 1991. Water treatment without waste materials - fundamentals and state of the art of pellet softening. Journal of Water Supply: Research and Technology - Aqua. 40(5), 263-280

Express Water 2019. User Manuals and Videos. https://www.expresswater.com/pages/user-manuals [accessed 30 April 2019]

Georgiou D., Bendos D., Kalis M., Koutis, C. (2018). Removal and/or prevention of limescale in plumbing tubes by a radio-frequency alternating electric field inductance device. Journal of Water Process Engineering. 22, 34-40

Hamouda M.A., Anderson W.B, Huck P.M. 2010. A framework for selecting POU/POE systems. Journal American Water Works Association. 102(12), 42-56 
Hofman J., van der Hoek J.P., Nederlof M., Groenendijk M. 2007. Twenty years of experience of centralised softening in the Netherlands: water quality, environmental benefits, and costs. Water 21, 21-24

Höll W.H., Hagen K. 2002. Partial demineralisation of drinking water using carbon dioxide regenerated ion exchangers. Water Science and Technology: Water Supply. 2(1), 57-62.

Hoslett J., Massara T.M., Malamis S., Ahmad D., van den Boogaert I, Katsou E., Ahmad B., Ghazal H., Simons S., Wrobel L., Jouhara H. 2018. Surface water filtration using granular media and membranes: A review. Science of the Total Environment. 639, 1268-1282

van den Hoven T., Tielemans M., Buijs P. 1998. Remedial actions to reduce lead in drinking water in the Netherlands. Water Supply, 16(1-2), 607-609

Hydropath 2019. Hydropath Technology product brochure. http://hydropath.com/wpcontent/uploads/2017/10/hydropath_brochure.pdf [accessed 30 April 2019]

Mons M., van Dijk H., Gatel D., Hesse S., Hofman J., Nguyen M.-L., Slaats N. 2007. Drinking water hardness: reasons and criteria for softening and conditioning of drinking water. Technical report. Global Water Research Coalition.

Royal HaskoningDHV 2019. Kostenstandaard drinkwater (cost standard for drinking water projects). https://www.kostenstandaard.nl/ [accessed 30 April 2019]

Veolia 2018. Personal communications with chief process engineer Peter B. Nielsen and sales engineer Dipl.Ing. Uwe Sauer. November 2018

Wessels P., Galama-Tirtamarina A. 2018. Mogelijkheden levering 3 miljoen $\mathrm{m}^{3} /$ jaar van PS Beilen naar PS Terwisscha (Vitens) (Possibilities for delivering 3 million $\mathrm{m}^{3} / \mathrm{year}$ from PS Beilen to PS Terwisscha (Vitens)). WMD Technical report, 6 April 2018, Assen, the Netherlands

WHO (2011). Hardness in Drinking-water: Background Document for Development of WHO Guidelines for Drinking-water Quality. Report. WHO/HSE/WSH/10.01/10/Rev/1 


\section{Tables}

Table 1 Technologies for centralised and decentralised drinking water softening.

\begin{tabular}{|c|c|c|c|}
\hline $\begin{array}{l}\text { Hardness removal } \\
\text { mechanism }\end{array}$ & Technology & $\begin{array}{l}\text { Centralised } \\
\text { softening }\end{array}$ & $\begin{array}{l}\text { Decentralised } \\
\text { softening }\end{array}$ \\
\hline \multirow[t]{2}{*}{ Crystallisation/precipitation } & Pellet softening ${ }^{2}$ & $\mathrm{x}$ & \\
\hline & $\begin{array}{l}\text { Lime-soda ash } \\
\text { softening } 2,3\end{array}$ & $x$ & \\
\hline \multirow[t]{2}{*}{ Ion exchange } & $\begin{array}{l}\text { Strong acid cation } \\
\text { exchange } 3,4\end{array}$ & $x$ & $x$ \\
\hline & $\mathrm{CARIX}^{\circledR} 2$ & $x$ & \\
\hline \multirow{2}{*}{$\begin{array}{l}\text { Pressure driven } \\
\text { membrane separation }\end{array}$} & Nanofiltration 2,3 & $x$ & \\
\hline & Reverse osmosis ${ }^{2,3}$ & $x$ & $x$ \\
\hline $\begin{array}{l}\text { Electric-driven membrane } \\
\text { separation }\end{array}$ & Electrodialysis ${ }^{3}$ & $x$ & \\
\hline $\begin{array}{l}\text { Temperature-driven } \\
\text { distillation }\end{array}$ & $\begin{array}{l}\text { Temperature-driven } \\
\text { distillation }\end{array}$ & $x$ & $x$ \\
\hline \multirow[t]{2}{*}{ Chemical scale control } & Chelation ${ }^{3}$ & & $x$ \\
\hline & Sequestration ${ }^{3}$ & $x$ & \\
\hline \multirow[t]{3}{*}{$\begin{array}{l}\text { Physical water } \\
\text { conditioning devices }^{1}\end{array}$} & $\begin{array}{l}\text { Electronic and } \\
\text { electrostatic devices }{ }^{4,5}\end{array}$ & & $x$ \\
\hline & Electrolytic devices ${ }^{4}$ & & $x$ \\
\hline & $\begin{array}{l}\text { Permanent magnets } \\
\text { and electromagnets } \\
4,5\end{array}$ & & $x$ \\
\hline
\end{tabular}

${ }^{1}$ Physical water conditioning devices do not soften the water by lowering water hardness, but claim to reduce lime scale formation (Georgiou et al., 2018)

$390 \quad{ }^{2}$ Mons et al., (2007)

$391 \quad{ }^{3}$ AWWA (2016b)

$392 \quad{ }^{4}$ BWT (2019a, 2019b)

$393 \quad{ }^{5}$ Georgiou et al. (2018) 
Table 2 Comparison of three different softening technologies for centralised water softening treatment at DWTP Beilen with a design capacity of $650 \mathrm{~m}^{3} / \mathrm{h}$.

\begin{tabular}{|c|c|c|c|}
\hline Indicator & CARIX $^{\circledR}$ & Nanofiltration & Pellet softening \\
\hline Hardness reduction & From 2 to $1.3 \mathrm{mmol} / \mathrm{L}$ & From 2 to $1.3 \mathrm{mmol} / \mathrm{L}$ & From 2 to $1.3 \mathrm{mmol} / \mathrm{L}$ \\
\hline $\mathrm{CCPP}_{90}$ & $0.25-0.30 \mathrm{mmol} / \mathrm{L}$ & $0.30-0.35 \mathrm{mmol} / \mathrm{L}$ & $0.25-0.30 \mathrm{mmol} / \mathrm{L}$ \\
\hline Water use (total) & $5.3 \%$ & $10.5 \%$ & $3.6 \%$ \\
\hline \multirow[t]{2}{*}{$\begin{array}{l}\text { Water treatment } \\
\text { residuals quantity }\end{array}$} & $\begin{array}{l}60 \text { tonnes of dry } \\
\text { solids per year (iron } \\
\text { sludge) }\end{array}$ & $\begin{array}{l}33 \text { tonnes of dry } \\
\text { solids per year (iron } \\
\text { sludge) }\end{array}$ & $\begin{array}{l}60 \text { tonnes of dry } \\
\text { solids per year (iron } \\
\text { sludge) }\end{array}$ \\
\hline & & & $\begin{array}{l}80 \text { tonnes of dry } \\
\text { solids per year (lime } \\
\text { sludge) }\end{array}$ \\
\hline $\begin{array}{l}\text { Softening treatment } \\
\text { residuals quantity }\end{array}$ & $\begin{array}{l}132,000 \mathrm{~m}^{3} \text { of eluate } \\
\text { per year }\end{array}$ & $\begin{array}{l}360,000 \mathrm{~m}^{3} \text { of } \\
\text { concentrate per year }\end{array}$ & $\begin{array}{l}290 \text { tonnes of pellets } \\
\text { per year }\end{array}$ \\
\hline $\begin{array}{l}\text { Softening treatment } \\
\text { residuals quality }\end{array}$ & $\begin{array}{l}\text { High minerals content } \\
\text { eluate }\end{array}$ & $\begin{array}{l}\text { High minerals content } \\
\text { concentrate with } \\
\text { antiscalant }\end{array}$ & $\begin{array}{l}\text { Yellow-white coloured } \\
\text { pellets (reusable) }\end{array}$ \\
\hline $\begin{array}{l}\text { Operating } \\
\text { requirements } \\
\text { softening technology }\end{array}$ & 2-4 hours per week & 4-8 hours per week & 8-12 hours per week \\
\hline $\begin{array}{l}\text { Cost per } \mathrm{m}^{3} \text { for } \\
\text { groundwater } \\
\text { treatment }\end{array}$ & USD $0.35-0.45$ per $\mathrm{m}^{3}$ & USD $0.35-0.45$ per $\mathrm{m}^{3}$ & USD $0.35-0.45$ per $\mathrm{m}^{3}$ \\
\hline $\begin{array}{l}\text { Cost per } \mathrm{m}^{3} \text { for } \\
\text { softening treatment }\end{array}$ & USD 0.15-0.17 per $\mathrm{m}^{3}$ & USD 0.16-0.18 per $\mathrm{m}^{3}$ & USD $0.18-0.20$ per $\mathrm{m}^{3}$ \\
\hline
\end{tabular}


Table 3 Comparison of three selected softening technologies for decentralised water softening or conditioning treatment.

\begin{tabular}{|c|c|c|c|}
\hline Indicator & $\begin{array}{l}\text { Cation exchange } \\
\text { ("traditional") }\end{array}$ & Reverse osmosis & $\begin{array}{l}\text { Electronic water } \\
\text { conditioning device }\end{array}$ \\
\hline Hardness reduction & $\begin{array}{l}\text { Total removal } \\
\text { possible }\end{array}$ & $\begin{array}{l}\text { Total removal } \\
\text { possible }\end{array}$ & None $^{1}$ \\
\hline $\begin{array}{l}\text { Level of } \\
\text { documentation }\end{array}$ & Well documented & Well documented & $\begin{array}{l}\text { Limited } \\
\text { documentation }\end{array}$ \\
\hline $\mathrm{CCPP}_{90}$ reduction & Low to high & High & None ${ }^{1}$ \\
\hline Water use (total) & $2.5-4.5 \%^{2}$ & $>100 \%^{3}$ & No water use \\
\hline $\begin{array}{l}\text { Softening treatment } \\
\text { residuals quantity }\end{array}$ & No solid residuals & No solid residuals & No residuals \\
\hline $\begin{array}{l}\text { Softening treatment } \\
\text { residuals quality }\end{array}$ & $\begin{array}{l}\text { High minerals content } \\
\text { eluate }\end{array}$ & $\begin{array}{l}\text { High minerals content } \\
\text { concentrate }\end{array}$ & No residuals \\
\hline $\begin{array}{l}\text { Maintenance } \\
\text { requirements }\end{array}$ & Low & Low & Low \\
\hline $\begin{array}{l}\text { Cost per } \mathrm{m}^{3} \text { for } \\
\text { softening treatment / } \\
\text { conditioning }\end{array}$ & USD 2.2 per $\mathrm{m}^{3}$ & $\begin{array}{l}\text { USD } 1.4 \text { per } \mathrm{m}^{3} \text { plus } \\
\text { the cost of water } \\
\text { discharged }\end{array}$ & USD 0.3 per $\mathrm{m}^{3}$ \\
\hline
\end{tabular}

${ }^{1}$ Hardness and $\mathrm{CCPP}_{90}$ are not affected, since physical water conditioning devices do not soften the water by lowering the calcium and magnesium content and do not radically alter the water chemistry.

${ }^{2}$ BWT (2019a, 2019c)

${ }^{3}$ Express Water (2019a) 


\section{Figures}
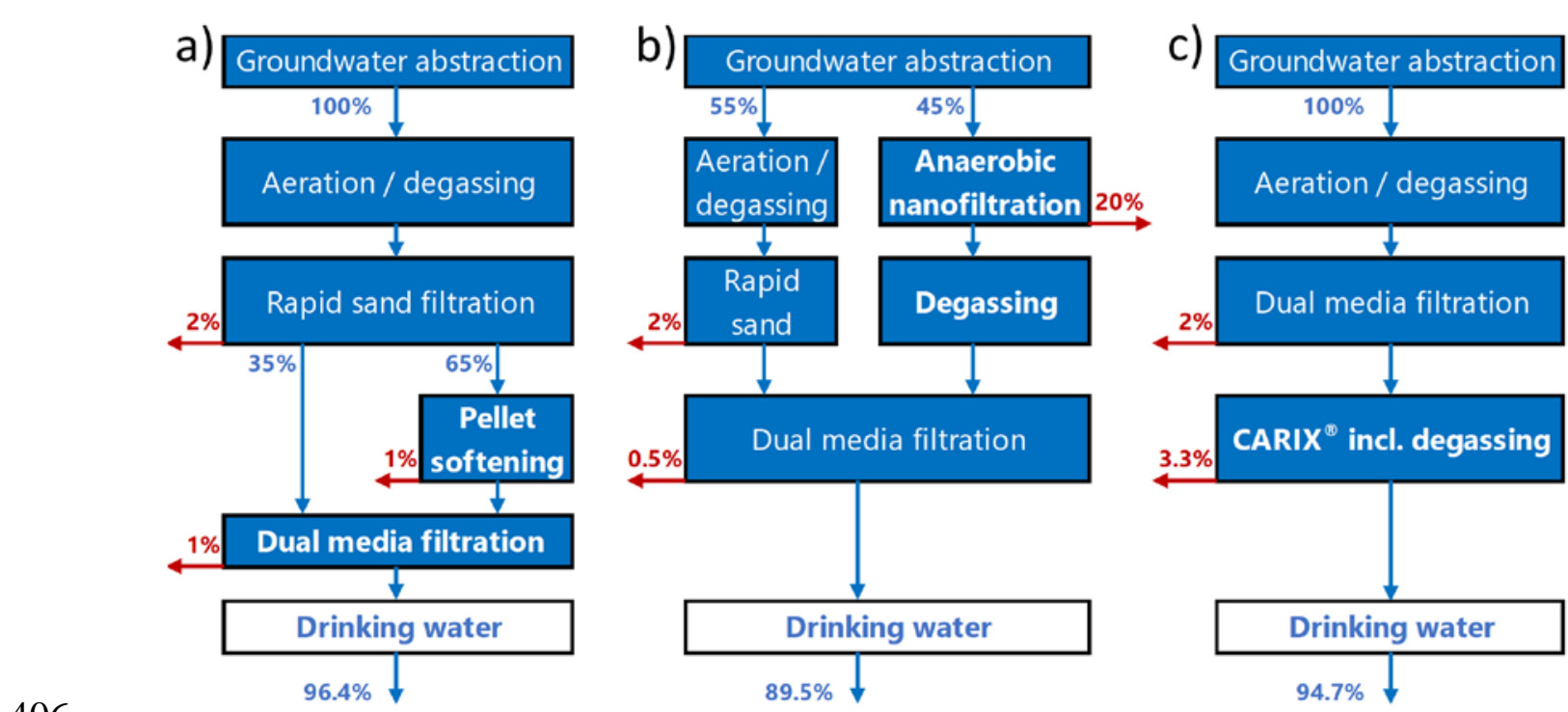

Figure 1 Potential water treatment schemes for Dutch DWTP Beilen with a) split stream pellet softening, b) split stream anaerobic nanofiltration and c) full stream CARIX ${ }^{\circledR}$ treatment. Blue (vertical) arrows represent drinking water flow and brown (horizontal) arrows represent wastewater flow. 